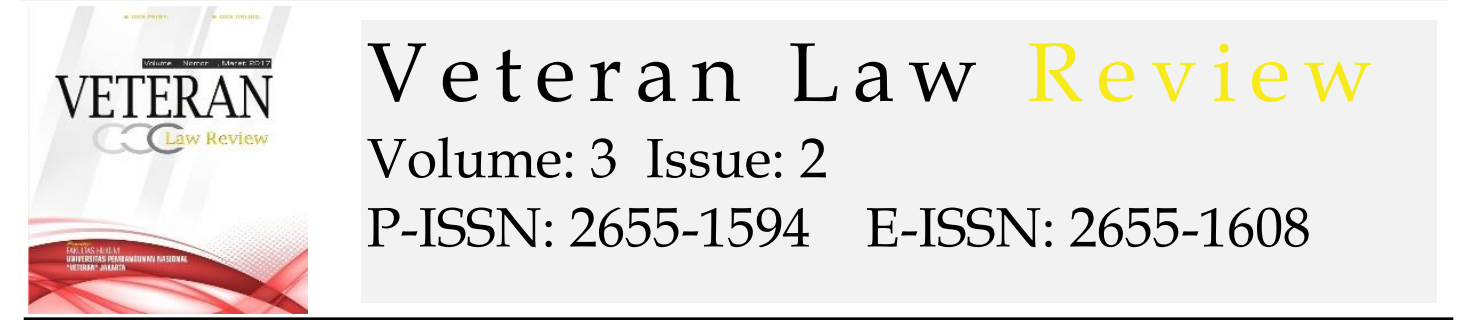

\title{
The Pretrial (Praperadilan) Filed By The Suspect With The Status Wanted List Of People (DPO)
}

\author{
Deni Setya Bagus Yuherawan ${ }^{1}$, Sieldy Aprilia ${ }^{2}$
}

${ }^{1}$ Faculty of Law, Trunojoyo Madura University, E-mail: deniyuherawan@trunojoyo.ac.id

${ }^{2}$ Faculty of Law, Trunojoyo Madura University, E-mail: sieldyaprilia96@gmail.com

\begin{tabular}{|c|c|}
\hline ARTICLE INFO & ABSTRACT \\
\hline $\begin{array}{l}\text { Keywords: } \\
\text { Pre-Trial; Suspect; } \\
\text { Wanted List Of People } \\
\text { How to cite: } \\
\text { Yuherawan, D. S. B., \& } \\
\text { Aprilia, S. (2020). The } \\
\text { Pretrial (Praperadilan) } \\
\text { Filed By The Suspect } \\
\text { With The Status } \\
\text { Wanted List Of People } \\
\text { (Dpo). Veteran Law } \\
\text { Review. 3(2). } 109 \text { - } 127\end{array}$ & $\begin{array}{l}\text { The granting of a Pre-trial petition filed by a suspect whose status is a } \\
\text { Wanted List of People (DPO) by the panel of judges is one of the actions } \\
\text { deemed to deviate from the rule of law. SEMA Number } 1 \text { of } 2018 \\
\text { concerning the Prohibition of Proposal for Pretrial by Escaping } \\
\text { Suspects or with the status of DPO has confirmed that pretrial } \\
\text { applications may not be filed by suspects who have fled or DPO in } \\
\text { another sense submitted by legal counsel or their families. In this case, } \\
\text { there is a legal problem, namely the conflict of norm values in a rule. So } \\
\text { this article is written to analyze whether pretrial filings made by } \\
\text { suspects with the status of a Wanted List or DPO can be justified or } \\
\text { not. This research is normative legal research that uses a statutory } \\
\text { approach (Statute Approach) and a conceptual approach (Conceptual } \\
\text { Approach). For this reason, the data that the authors use is secondary } \\
\text { data consisting of primary legal materials and secondary legal } \\
\text { materials. Primary legal materials consist of legal products such as } \\
\text { statutory regulations. Meanwhile, secondary legal materials consist of } \\
\text { journals and books that are relevant to research problems. The collected } \\
\text { data are then compiled, processed, and analyzed using prescriptive } \\
\text { analysis using substance comparisons so that it will answer the } \\
\text { problems. } \\
\text { Copyright @2020 VELREV. All rights reserved. }\end{array}$ \\
\hline
\end{tabular}

\section{Introduction}

The founders of the nation have made a firm promise that Indonesia is a country of law. This is expressly contained in the General Explanation of the 1945 Constitution item 1 which reads "The Indonesian State is based on the law (rechtstaat), not based on mere power (machtstaat)". After the third amendment, the conception of Indonesia as a rule of law was further emphasized in the body, namely in Article 1 paragraph (3) of the 1945 Constitution which reads "Indonesia is rechtstaat (rule of law)".1

As stated in the Indonesian Encyclopedia, it is written that a rule of law is a state that has the aim of being able to administer the law in an orderly and

1 Waluyo, Bambang. (2016). Penegakan Hukum di Indonesia. Sinar Grafika. (pp. 137). 
general manner that usually exists within the community of the country itself. The rule of law seeks to maintain public order so that everything runs according to the applicable law. ${ }^{2}$ As a rule of law, Indonesia should have created a law enforcement system capable of realizing justice and capable of creating harmony, peace, order, and welfare for the people. ${ }^{3}$ To create a law enforcement system that is by the objectives of the law, it should be based on statutory regulations in implementing law enforcement. As in the case of criminal law enforcement, it must be by Law Number 8 of 1981 concerning the Criminal Procedure Code (hereinafter referred to as KUHAP). In Article 1 of the Criminal Procedure Code, it has been written about the definition of a series of procedures in the law enforcement process in Indonesia. Besides, in this Criminal Procedure Code, we understand that all elements of the law enforcement apparatus have a role in the law enforcement process starting from the police, prosecutors, and courts to work together to achieve the purpose of the state of Indonesia as a rule of law is to regulate the welfare of the community based on applicable law. ${ }^{4}$

The fact is that in practice, it is not uncommon for law enforcement officers not to carry out their duties by the applicable laws. Usually, suspects who feel aggrieved for the implementation of inappropriate law enforcement by law enforcement officials in carrying out their duties, are outlined in pretrial filings by the suspect.

Pre-trial itself is one of the law enforcement processes listed in KUHAP, to be precise in CHAPTER X KUHAP. However, the existence of this pretrial process does not mean that pretrial can be used as a new institution or element in the court process, it's just that this is a form of granting authority by the Criminal Procedure Code to the law enforcement process within the court. As we know, basically the court has the authority and function to adjudicate and decide a case, but the existence of a pretrial makes the court itself has the right and authority to examine the lawfulness of detention, seizure, termination of the investigation, or termination of prosecution by investigators or public prosecutors. ${ }^{5}$

Article 1 point 10 of the Criminal Procedure Code affirms that "Pre-trial is the authority of the District Court to examine and decide according to the method regulated in this law, concerning:

1) Whether or not an arrest of funds or detention is valid at the request of the suspect or his family or other parties on the suspect's power;

2) Whether or not the termination of investigation or prosecution upon request is legal or not for the sake of upholding law and justice;

3) Requests for compensation or rehabilitation by the suspect or his family or other parties or proxies whose case has not been filed in court.

Ibid. (pp. 139)

Ibid. (pp. 136)

Hamzah, Andi. (2013). Hukum Acara Pidana Indonesia. Sinar Grafika. (pp. 4-7).

Harahap, M. Yahya. (2012) Pembahasan Permasalahan dan Penerapan KUHP Pemeriksaan

Pengadilan,Banding, Kasasi, Dan Peninjauan Kembali. Sinar Grafika. (pp. 1). 
Furthermore, what is formulated in Article 1 point 10 of the Criminal Procedure Code, is emphasized in Article 77 of the Criminal Procedure Code, which explains that "District Courts are authorized to examine and decide, by the provisions regulated in this law concerning:

1) Whether or not the arrest, detention, termination of investigation or prosecution is legal;

2) Compensation and/or rehabilitation for someone whose criminal case is terminated at the level of investigation or prosecution."

Currently, the Constitutional Court has added new objects to pretrial through decision Number 21 / PUU-XII / 2014, namely regarding the legal or invalid determination of suspects, searches, and confiscation. With this decision, the object of pretrial is not only limited to whether or not the arrest, detention, termination of investigation or prosecution, as well as compensation and/or rehabilitation as previously regulated in the Criminal Procedure Code, but also whether the determination of a suspect is legal or not, searches. and confiscation which had not previously been regulated in the Criminal Procedure Code.

The additional authority was not balanced with sufficient regulation in pretrial because the Constitutional Court decision Number 21 / PUU-XII / 2014 did not regulate legal subjects as pretrial applicants so that there was a legal vacuum which resulted in not applying legal certainty. For example, the District Court examines a pretrial request submitted by a suspect who is a fugitive (DPO). As in the case of La Nyalla Mattaliti, who filed a pretrial on the determination of the suspect through his attorney and his family.

La Nyalla was named a suspect in the case of misuse of the East Java Provincial Government grant funds amounting to Rp. 5.3 billion for the purchase of an IPO (Initial Public Offering) of Bank Jatim. The status of DPO (List of People Wanted) was determined by the East Java High Prosecutor's Office, after La Nyalla Mattalitti failed to fulfill the summons for examination three times. The suspect La Nyalla Mattalitti filed a pretrial for the determination of the status of the suspect in the alleged corruption of misuse of grant funds through his legal advisor when he was not in Indonesia and had been declared a fugitive (DPO). ${ }^{6}$ After winning the pretrial against the status of a suspect in the East Java Kadin grant, La Nyalla Mattalitti was again named a suspect by the East Java Prosecutor's Office and again filed a pretrial on behalf of his son Muhammad Ali Affandi. ${ }^{7}$

$6 \quad$ Ferdinan. Sidang Praperadilan La Nyalla Digelar Hari Ini. Retrieved March 30, 2016 from https://m.detik.com/news/berita/3175470/sidang-praperadilan-la-nyalla-digelarhari-ini

$7 \quad$ Elza Astari Restaduari. La Nyalla Kembali Ajukan Praperadilan Kini Atas Nama Anaknya. Retrieved May 6, 2016 from https://m.detik.com/news/berita/3203588/la-nyallakembali-ajukan-praperadilan-kini-atas-nama-anaknya, 
Regarding whether or not a suspect can be submitted to a pretrial, his whereabouts are not known, such as a suspect who has been designated as a Wanted List (DPO) who filed a pretrial through his family or legal advisor. At this time, SEMA No.1 of 2018 concerning the Prohibition of Submission of pretrial for suspects who have fled or are currently in the status of a wanted list (DPO) applies.

\section{Problem}

Based on the background that has been described, there are problem formulations that need to be analyzed, namely: is it justifiable for a suspect who has the status of a DPO (wanted list) to file a pretrial on whether or not his determination to be a suspect is legal?

\section{Research purpose}

The purpose of this writing is to find out whether the pretrial submission of the determination of a suspect by a suspect who has been designated as a DPO (wanted list) can be legally justified.

\section{Discussion}

\subsection{Legal Consequences of Pre-Trial Decisions by Suspects with the Status of the Wanted List (DPO)}

In law enforcement practice, pretrial filing is an effort made to test the legality of the actions of law enforcement officials in carrying out law enforcement efforts. The pre-trial establishment aims to enforce the law fairly. Enforcing the law fairly means that in carrying out law enforcement efforts it is carried out by the applicable laws and regulations so that no party feels disadvantaged for actions taken by law enforcement officers. To enforce the law fairly, the state not only guarantees the protection of human rights for the suspects but also must pay attention to public justice.

As a rule of law, all legal actions taken must be based on law and not based on power. In essence, the law functions as a medium to achieve the goals of the State, namely to build an orderly and balanced society. ${ }^{8}$ However, if we look at the development of the law today, it is as if the law is being implemented to achieve a personal interest. So that the law is no longer applied as regulated in the Criminal Procedure Code. For example, a suspect who made various attempts to release himself from the legal process by taking advantage of pretrial institutions.

Through pretrial efforts, the suspect will try to convince the judge that the suspect has been harmed by the actions of law enforcement officials that were not based on statutory regulations. The various arguments presented by the

8 Santoso, L. \& Yahyanto. (2016). Pengantar Ilmu Hukum. Setara Press. (pp. 76). 
suspect were aimed at making the judge decide that the actions of the law enforcement officers were illegal. With the passing of a decision stating the invalidity of the actions of law enforcement officials, it is intended that the suspect can be freed from the legal process.

Pre-trial efforts are a right for suspects as a form of protection of human rights for law enforcement efforts. To realize a fair law enforcement system, it is necessary to have a balance between the rights provided by law and the obligations that must be carried out by the recipient of the rights. What is meant by the balance between rights and obligations is that in addition to exercising their rights, suspects must also have legal awareness in carrying out their obligations to obey the law.

Article 31 paragraph (1) Perkap Number 14 of 2012 concerning Management of Criminal Investigation, has explained that law enforcers can register a suspect's name in the Wanted List (DPO) after three consecutive failures to fulfill the investigator's summons and the suspect's whereabouts are not known. But in fact, the pretrial petition is used by the suspect as a medium for self-defense. Not infrequently suspects prefer to submit a pretrial request before they fulfill their obligation to fulfill the investigator's summons to be examined on suspected cases. Examples of cases related to the submission of pretrial applications for the determination of suspects by suspects whose names are on the wanted list (DPO) pretrial filed by La Nyalla Mahmud Mattalitti, the author of which is based on the Pre-trial Decision Number 19 / PRA.PER / 2016 / PN.SBY

The chronology of the case is as follows: the suspect's full name is Ir. H. La Nyalla Mahmud Mattalitti, who works as general chairperson of the East Java Chamber of Commerce and Industry, filed a legal filing as outlined in a pretrial petition against his recognition as a suspect in a criminal case of use of corruption and grants to purchase the Bank Jatim Initial Public Offering (IPO) at the Chamber of Commerce and Industry of East Java Province in 2012. This case began when the suspect, as the chairman of the East Java Chamber of Commerce and Industry, agreed to a collaboration between the East Java Provincial Government, represented by Dr. H. Soekarwo with the East Java Chamber of Commerce and Industry (KADIN) regarding East Java Economic Development.

After the suspect signed the cooperation, consecutively from 2011 to 2014 the East Java provincial government through the Regional Secretariat's Regional Secretariat SKPD has provided grant funds to the East Java Chamber of Commerce in the amount of approximately Rp. 48,000,000,000 (forty eight billion rupiah). The amount of money given is being accordance with the contents of the Regional Grant Agreement (NPHD) and the integrity which has been signed by the Chairman of the East Java Chamber of Commerce and Industry H. Ir. La Nyalla M Mattalitti. The grant funds received by the East Java Chamber of Commerce and Industry in 2012 should be used as in the proposed proposal. 
However, the suspect, the grant funds received by Kadin in 2012 were not used as intended, and the amount used at that time reached Rp.10,000,000,000 (ten billion rupiahs). This violates the contents of the Regional Grant Submission Text (NPDH) that has been agreed upon. Suspect H. IR. La Nyalla M Mattalitti used the money to purchase the Bank Jatim IPO. The purchase was made by transferring the savings book from the East Java Kadin account in the name of the East Java Provincial Kadin to the suspect's account. This action was carried out at the Main Branch of Bank Jatim, Surabaya.

The funds transferred were Rp. 5,359,479,150 (five billion three hundred and fifty-nine million four hundred seventy-nine thousand one hundred and fifty rupiahs), used for the purchase of 12,340,500 IPO shares of Bank Jatim. Furthermore, in 2013 the suspect sold Bank Jatim shares with a total value of Rp. 4,335,000,000 (four billion three hundred and thirty-five million rupiahs), and in 2015 the suspect sold back shares of Bank Jatim three times with a total value of Rp. 6,411,992,500 (six billion four hundred eleven million nine hundred ninety-two thousand five hundred rupiahs).

There is a difference in the sale of shares amounting to Rp. 1,105,577,500 (one billion one hundred five million five hundred seventy-seven thousand five hundred rupiahs), which is the result of Rp. 6,411,992,500 less the purchase of shares worth Rp. 5,359,479,150. These results were enjoyed by H. Ir. La Nyalla M Mattalitti using state funds. So that in this case, H. Ir. La Nyalla M Mattalitti was named a suspect. The East Java High Prosecutor's Office of East Java had summoned him as a suspect 3 (three) times. The first summons was made on March 16, 2016, then the second summons was made on March 21, 2016, and the last summons was made on March 24, 2016.

During the three summons, La Nyalla Mattalitti was not present to meet the summons, in the third summons made on March 24. with orders to the officers to bring the suspect to the investigator, the investigator has tried to come to La Nyalla Mattaliti's residence but to no avail, the suspect is unknown. so that on March 29, 2016, Ir. H. La Nyalla M Mattalitti has been stipulated in the List of Wanted Persons (DPO) bye Letter of Determination of the Search for the Head of the East Java High Prosecutor's Office Number: KEP-17 / O.5 / Fd.1 / 03/2016 dated 29 March 2016 regarding the determination of the suspect H. Ir. La Nyalla M Mattalitti as a fugitive and included in the wanted list (DPO).

One of the reasons for the pretrial petition, in this case, was that the applicant felt that there was no prior examination regarding the applicant's appointment as a suspect by the defendant for the use of the East Java Kadin grant to purchase an Initial Public Offering (IPO) for personal gain. ${ }^{9}$ In response to the reasons submitted by the applicant, the respondent responded that since the beginning of the investigation and determination made on the suspect it was not a new investigation process, but the suspect has been examined as a witness in a completed criminal case under the name of the suspect Diar

$9 \quad$ Putusan Praperadilan Nomor 19/Pra.Per/2016/PN.Sby, (pp. 14) 
Kusuma, SE and Ir. . Nelson Sembiring, M.Eg. Furthermore, the summoning process if the applicant has been carried out three times, but the applicant does not have the good faith to fulfill the summons until the applicant is designated as a Wanted List (DPO). ${ }^{10}$ Decision Number 19 / Pra.Per / 2016 / PN.Sby Hakim granted the pretrial request submitted by the applicant through his legal attorney because the judge did not consider the suspect's status as a DPO.

Accepting a pretrial petition by a suspect whose name is included in the Wanted List (DPO) can certainly have legal consequences. Legal consequences are everything that arises as a result of legal actions committed by legal subjects (Achmad Ali, 2008: 192). Legal consequences are also referred to as events that arise as a result of actions carried out by legal subjects that are already by legal regulations or that deviate from the legal rules themselves. ${ }^{11}$ The granting of the pretrial petition in the La Nyalla M Mattalitti case will bring up a negative perspective from the community, later the public will argue that the law enforcement process can be completed only through a pretrial request, even if this is a weapon the suspect can use to free himself from criminal cases The suspect would prefer to run away rather than fulfill his obligations. Of course, this will have an impact on the investigation process, the investigation process will be hampered even though basically the pretrial request for the determination of the suspect is accepted does not abort the investigator's authority to issue an investigation warrant (Sprindik). The investigator has the authority to continue the investigation after finding that there are at least two valid pieces of evidence. ${ }^{12}$

It can be said that the case handlers with the suspect H. Ir, La Nyalla M Mattalitti were not following the principle of legal certainty. The receipt of the suspect's pretrial petition has delayed the legal handling of this case. This contradicts the principle of fast, simple, and low-cost trial as stated in Article 4 paragraph (2) of Law Number 48 of 2009 concerning Judicial Power. Besides, the judge granted the pretrial request filed by La Nyalla M Mattalitti without considering the suspect's status as a DPO, so it can be said that this decision deviates from the purpose of pretrial existence, where the purpose of pretrial is only to supervise whether there is coercion in the investigation process, detention, and prosecution. committed by law enforcement agencies in criminal proceedings. ${ }^{13}$ Meanwhile, it is clearly stated in the investigator's reasons for determining La Nyalla M Mattalitti as a DPO due to the lack of good faith from the suspect to fulfill the summons for examination three times in a row and the suspect cannot be found at his residence until the suspect is named DPO. So that during the investigation process there is no element of coercion by the investigator in handling this case, the judge should have considered this in his decision. Apart from that, based on the principle of

$10 \quad$ Putusan Praperadilan Nomor 19/Pra.Per/2016/PN.Sby, (pp. 51-53)

11 Pengertian Akibat Hukum, Retrieved January 14, 2017 from https://www.suduthukum.com/2017/01/pengertian- akibat-hukum.html?m=1

12 Pasal 2 Ayat (3) Peraturan Mahkamah Agung Republik Indonesia Nomor 4 Tahun 2016 tentang Larangan Peninjauan Kembali Putusan Praperadilan

13 Purba, Tumian Lian Daya. (2017). Praperadilan Sebagai Upaya Hukum Bagi Tersangka. In Papupa Law Journal. 1(2). (pp. 265) 
Equality Before The Law that everyone has the same treatment before the law, then La Nyalla M Mattalitti as an element of society who is considered to understand the law can uphold the principles upheld in state law and he can have good faith to fulfill the inspection according to the rules. So in this case the author thinks that pretrial filings by suspects with the status of DPO (wanted list of persons) cannot be legally justified because they have deviated from the purpose of the pretrial existence.

\subsection{Submission of pretrial applications by suspects whose names are included in the wanted list (DPO)}

Pre-trial is a trial process conducted before the main trial case is heard. Pretrial in this case only examines the process of legal action by law enforcement officials in carrying out law enforcement which includes investigation and prosecution, not on the subject matter or the material of the case. ${ }^{14}$

The pretrial process cannot be said to be the main duty and function of the court in handling criminal acts, because the main task of the court in handling the subject matter of the case is the final decision of the criminal act. ${ }^{15}$ Pre-trial has been regulated in the provisions of Article 77 Law Number 8 of 1981 concerning the Criminal Procedure Code, which explains that "District courts have the authority to examine and decide in by the provisions stipulated in this law, concerning:

1) Legal or not arrest, detention, cessation of investigation or cessation of prosecution;

2) Compensation and/or rehabilitation of a person whose criminal case is terminated at the level of investigation and prosecution.

The explanation regarding pretrial, arrest and detention has also been described in Article 1 Number 10, Article 1 Number 20, and Article 1 Number 21 KUHAP. Article 1 point 20 of the Criminal Procedure Code explains that "an arrest is an act of an investigator in the form of temporarily restricting the freedom of a suspect or defendant if there is sufficient evidence to investigate and prosecuting funds or judiciary in matters and according to methods regulated in this law."

The meaning of temporary restraint of a suspect's freedom as stipulated in Article 1 point 20 of the Criminal Procedure Code is physical restraint or physical custody which has the meaning of placing a person under certain supervision and in a predetermined place. Meanwhile, the definition of detention is as stipulated in Article 1 point 21 of the Criminal Procedure Code.

Article 1 point 21 of the Criminal Procedure Code states that "detention is the placement of a suspect or defendant in a certain place by an investigator, or public prosecutor or judge by his determination, in matters as well as those

\footnotetext{
14 Hartono. (2012). Penyidikan dan Penegakan Hukum Pidana Melalui Pendekatan Hukum Progresif. Sinar Grafika. (pp. 81).

15 Soeparmono, Op.Cit. (pp. 12)
} 
regulated in this law." Based on these provisions, it could be seen that the physical appearance of the suspect could be identified.

Pre-trial is a new authority delegated to the court, the additional authority is intended to protect the rights of the suspect from arbitrary actions by the investigator in determining a person as a suspect, so that the person labeled as a suspect can test the legality and purity of the determination of the suspect through pretrial. ${ }^{16}$

However, in law enforcement practice, granting a suspect the right to test the legality of a suspect's determination is a way for the suspect to escape legal bondage by running away or purposely disappearing until he is designated as a Wanted List (DPO) to avoid legal proceedings and then submits a pretrial. for the determination of the suspect, because as we know that in this case the suspect was neither detained nor arrested.

Article 1 point 10 letter a of the Criminal Procedure Code explains that to test the legality of an arrest or detention, the suspect or his family or other party is filed by the suspect. Article 1 point 10 of the Criminal Procedure Code also explains that whether or not the arrest or detention is legal, the termination of investigation or the termination of prosecution and requests for compensation and rehabilitation are pretrial objects.

The appointment of a suspect as a pretrial object began when the South Jakarta District Court received a pretrial request for the suspect's determination submitted by the Commissioner-General of Police Drs. Budi Gunawan as in decision Number: 04 / Pid.prap / 2015 / PN.Jkt.Sel, where when submitting pretrial the applicant does not have the status of a wanted list (DPO) so in this case, it is not regulated regarding the pretrial petition for the determination of a suspect by the suspect who has DPO status.

In practice, the District Court has received a pretrial request for the determination of a suspect, while the Criminal Procedure Code does not regulate the determination of the suspect as the pretrial object, so in this case to provide legal certainty the Constitutional Court through its decision Number 21 / PUU-XII / 2014 has expanded the pretrial object previously regulated in Law Number 8 of 1981 concerning the Criminal Procedure Code, one of which is the determination of a suspect. Regarding the expansion of the pretrial object, as in the Constitutional Court decision Number, 21 / PUU-XII / 2014 in its amendment states: ${ }^{17}$

1) Grant the request of the applicant for a part

a. The phrases "preliminary evidence", "sufficient evidence", and "sufficient evidence" as specified in Article 1 number 14, Article 17, and Article 21 paragraph (1) of Law Number 8 of 1981 on the Book of the Criminal Procedure Law (State Gazette of the Republic of Indonesia of 1981, Number 76, Supplement to the State Gazette of the Republic of

\footnotetext{
16 Ilyas, Amir \& Nusa, Apriyanto. Op.Cit, (pp. 56)

17 Kutipan Amar Putusan Mahkamah Konstitusi Nomor 21/PUU-XII/2014
} 
Indonesia of 1981 Number 3209) is contrary to the Constitution of the Republic of Indonesia of 1945 as long as it is not interpreted as "preliminary evidence", "sufficient preliminary evidence ", And" sufficient evidence", are at least two instruments of evidence contained in Article 184 of Law No. 8 of 1981 on Criminal Procedure Law;

b. The phrase "initial evidence". "Sufficient evidence of origin" and "sufficient evidence", as specified in Article 1 number 14, article 17, Article 21 paragraph (1) of Law No. 8 of 1981 on Criminal Procedure Law (State Gazette of the Republic of Indonesia of 1981, Number 76, Supplement to the State Gazette of the Republic of Indonesia No. 3209) has no binding legal force as long as it is not defined that "preliminary evidence", "sufficient preliminary evidence", and "sufficient evidence" are at least two means of evidence contained in Article 184 of the Law Number 8 of 1981 on Criminal Procedure Law;

c. Article 77 letter of Law No. 8 of 1981 on Criminal Procedure Law (State Gazette of the Republic of Indonesia Number 76 Supplement to State Gazette No. 3209) is contrary to the Constitution of the Republic of Indonesia as long as it is not included including the determination of suspects, searches and seizures;

2) Reject applications from applicants other than and the rest;

3) Order the posting of this decision in the State Gazette of the Republic of Indonesia as appropriate.

Based on the Constitutional Court decision Number 21 / PUU-XII / 2014, to determine a person as a suspect, the Constitutional Court has firmly stated that what is meant by preliminary evidence is at least two pieces of evidence that are considered sufficient. As stated in Article 1 number 14 KUHAP, Article 17, and Article 21 paragraph (1) and Article 184 KUHAP. Also, suspects must be investigated, except in criminal cases where the suspect may not be present (in absentia).

Article 1 point 14 of the Criminal Procedure Code which explains that "A suspect is a person who because of his actions or circumstances, based on preliminary evidence, is reasonably suspected of being the perpetrator of a criminal act", based on these provisions, further regulated in Article 50 paragraph (1) of the Criminal Procedure Code explains that "The suspect has the right immediately receive an examination by the investigator and then can be submitted to the public prosecutor. "Furthermore, to prepare a defense, as in the provisions of Article 51 letter (a) it explains that "a suspect has the right to be informed in a language that is understood by him about what was suspected to him when the examination began."

In principle, a suspect has the right to have an examination conducted by an investigator, as stated in Article 112 paragraph (1) of the Criminal Procedure Code that in conducting an examination an investigator must also clearly state the reasons why a person is considered a potential suspect and have the right to bring witnesses to be examined. Regarding the right of a suspect to receive this examination following Article 50 paragraph (1) of the Criminal Procedure 
Code, which is further explained in paragraph (2) of Article 112 of the Criminal Procedure Code, it is further elaborated that "the person who is summoned is obliged to come to the investigator and if he does not come, the investigator calls again, with orders for officers to bring to him. "

The word "obligatory" as stipulated in Article 112 paragraph (2) has the meaning that it must be done, not to be done (abandoned), as it should be. ${ }^{18}$ Based on this, it can be concluded that a person who has been declared a suspect should fulfill the investigator's summons for examination. Because the suspect should fulfill the summons of the investigator to get an examination, in this case, the suspect's physical presence can be known. However, it is different from the case where the suspect is in absentia, which is a criminal act which allows the suspect not to be present at the examination so that it is not necessary to examine the suspect. potential suspect.

In absentia in Latin which means "absence". whereas in legal terms, in absentia is referred to as one of the efforts made to complete a legal process of a criminal act by trying and punishing a defendant without having the defendant's direct presence. The Criminal Procedure Code has not been regulated in absentia. There are only a few articles that contain this matter, for example, Article 196 and Article 214, both articles discuss in a limited manner regarding judiciary in absentia. Several elements must be fulfilled in the trial in absentia itself, for example, the long-distance so that the defendant cannot attend the trial and without clear reasons, the defendant does not fulfill the summons even though he has been legally summoned. ${ }^{19}$

The implementation of the In absentia trial was aimed at preventing the accused from avoiding being examined in a court. However, the Criminal Procedure Code itself did not regulate the In absentia because the defendant fled and did not fulfill the summons for the examination so that the trial process was hampered. Because the escape of the defendant or the DPO made it difficult to prove guilt and the loss of the defendant's rights during the trial. There is an exception for defendants who are not present for obvious reasons such as illness, unable to attend, who have received direct permission from the judge based on the notification given by the defendant to the panel of judges. ${ }^{20}$

The principle of the presence of a defendant in the process of examining a criminal case as stipulated in Article 12 paragraph (1) of Law Number 48 of 2009 concerning Judicial Powers has an exception, namely the In absentia judiciary. One of the regulations regarding the In absentia judiciary is regulated in the provisions of Article 38 paragraph (1) of Law Number 20 of 2001 concerning Amendments to Law Number 31 of 1999 concerning Eradication of Corruption Crime which states that "If the defendant has been

\footnotetext{
18 Kamus Besar Bahasa Indonesia Versi Online, Retrieved July 15, 2017 from https://kbbi.web.id/>wajib

19 Mangoli, Arly Y. (2016). Eksistensi Peradilan In Absentia Dalam Hukum Acara Pidana Di Indonesia Menurut KUHAP. In Journal. 5(3). (pp. 67)

20 Ibid, (pp. 69)
} 
summoned legally is not present. in court without a valid reason, the case can be examined and decided without his presence. "

In addition to the principle of the presence of a defendant in the process of investigating a criminal case as referred to in Article 12 paragraph (1) of Law Number 48 of 2009, SEMA Number 6 of 1988 provides instructions for judges to refuse Tedakwa Legal Counsels or Lawyers who represent defendants who deliberately do not want to attend even though they have the summoning was carried out appropriately, in which case this raised the suspicion that the accused deliberately did not want to attend to benefit himself but otherwise could obstruct the proceedings of the court examination and the implementation of the verdict.

The same thing is also regulated in SEMA No.1 of 2012 concerning Submission of Applications for Reconsideration in Criminal Cases, it is explained that requests for reconsideration of the determination of a suspect or defendant in a criminal case can only be carried out by the convict himself or his heirs provided the convict has died. So that if there is a request for reconsideration submitted by the convict's attorney without the convict's in person, the application must be declared rejected or not accepted. The existence of SEMA Number 6 of 1988 Concerning Legal Counsels or Lawyers Receiving Authorization from the Defendant / Convicted "In Absentia" and SEMA Number 1 of 2012 Concerning Submission of Applications for Reconsideration in Criminal Cases aims to close the gap for defendants or convicts to avoid legal proceedings, especially against the defendant or convict with the status of the wanted list (DPO).

The Supreme Court has made an effort in the case of a pre-trial application filed by a suspect with the status of the People's Livelihood List (DPO), to provide legal certainty, the MA prescribes three guidelines among them:

1) A suspect who has fled or himself is in the status of the wanted list (DPO) cannot file a pretrial request;

2) If the application is still made by the legal counsel or his family, then the Judge has the right to state that the application cannot be accepted or rejected;

3) No legal action can be taken against the decision.

The issuance of a Supreme Court Circular hereinafter referred to as SEMA, is a legal policy carried out by the Supreme Court to fill the legal vacuum, considering that pretrial requests by suspects whose status as DPOs submitted through legal advisors or their families have not been regulated by legislation or the Criminal Procedure Code.

In the provisions of Article 2 of the Supreme Court Circular Letter Number 1 of 2018 concerning the Prohibition of Submission of Preliminary Filings for Suspects Who Run Away or Are in the Status of a Wanted List (DPO) in essence, it explains that the pretrial filed by the suspect's attorney and the 
suspect's family when the suspect is on a Search List Person (DPO) cannot be accepted.

Furthermore, returning to the discussion of Article 1 point 10 of the Criminal Procedure Code which distinguishes pretrial subjects as follows:

1) A suspect or suspect's family or a suspect's attorney on the power of a suspect to test whether or not detention and or arrest is legal

2) The third-party with an interest in testing whether or not the termination of investigation or prosecution is valid

3) The suspect or the suspect's family or the suspect's attorney on the power of the suspect to ask for compensation or rehabilitation

The pretrial request filed by the suspect's legal counsel or the suspect's family as stipulated in Article 1 number 10 letter a of the Criminal Procedure Code is confirmed in Article 79 of the Criminal Procedure Code that "A request for an examination of whether an arrest or detention is legal or not is submitted by the suspect, his family, or his proxies to the head of the district court with mention the reason. "The meaning of the word "or" in the formulation of the article is a link to mark a choice between several things (options). ${ }^{21}$

Based on the formulation of article 1 number 10 letter a KUHAP and Article 79 KUHAP, it can be concluded that the subjects of the pretrial applicant include:

1) The suspect

2) The suspect's family

3) The suspect's attorney by granting power of attorney by the suspect

Apart from the suspect, the Criminal Procedure Code also grants the legal counsel of the suspect to become the subject of a pretrial applicant to represent the suspect. This is based on the provisions in Article 54 of the Criminal Procedure Code which states that "in every examination process, a suspect or defendant has the right to legal assistance." As the subject of pretrial petitioners, legal advisors have to assist the legal process against suspects to enforce the law fairly. This means that in this case, legal advisors should not be fraudulent in carrying out their duties, for example making it difficult to investigate suspects by preventing investigators from examining suspects or by hiding the suspect.

Meanwhile, what is meant by "family" as the subject of pretrial applicants, KUHAP does not provide a clear definition. If we trace the contents of the Criminal Procedure Code, actually the term "family" can be seen in the provisions of Article 168 of the Criminal Procedure Code which emphasizes witnesses whose statements cannot be heard. ${ }^{22}$ As for the provisions of Article 168 of the Criminal Procedure Code, it is clear that "unless stipulated otherwise in this law, the statement cannot be heard and can resign as a witness:

21 Kamus Besar Bahasa Indonesia Versi Online, Retrieved May 20, 2020 from https://kbbi.web.id/

22 Ilyas, Amir \& Nusa, Apriyanto, Op.Cit, (pp. 10) 
a. Family by blood or a family in a straight line up or down to the third degree and the accused or who is together as the defendant;

b. Brothers of the defendant or who are together as the defendant, the father's mother or brother, or those who are related by marriage and the children of the accused's relatives up to the third degree;

c. The husband or wife of the defendant even though they are divorced or are joint as the defendant".

Regarding the family as the subject of the pretrial applicant for the determination of the suspect, the district court has received a pretrial application submitted by the suspect's family in decision Number 28 / Praper / 2016 / PN.Sby. The pretrial application for the determination of the suspect was submitted by Muhammad Ali Affandi, where the petitioner is the biological son of Ir. H. La Nyalla Mahmud Mattalitti. Muhammad Ali Affandi submitted a pretrial application for the determination of the suspect against his father. As in the argument of the petition, it states that because in this case, the investigator has determined the applicant's father as a suspect, the petitioner as a natural child is an interested third party, so that he has constitutional rights as the petitioner and has a legal interest in the case a quo.

The pretrial petition for the determination of the suspect is filed by the suspect's child where when the pretrial application is filed, the suspect is not in Indonesia or this case the status of the wanted list (DPO). This was stated by the respondent in his exception that the suspect H. Ir. La Nyalla Mahmud Mattalitti deliberately fled or hid abroad that did not have an extradition agreement with Indonesia to avoid his obligation to face the investigation process that was suspected of him.

Regarding the legal standing in the Petitioners' petition arguing that they are "interested third parties", as we know that "interested third parties" as one of the pretrial petitioners, KUHAP did not provide an official explanation.

When examined in jurisprudence, the sentence "interested third parties" formulated in the Criminal Procedure Code are grouped as terms that have many meanings or broad terms. ${ }^{23}$ Thus, the Constitutional Court interprets the third parties with an interest through the Constitutional Court decision Number 98 / PUU-X / 2012 which in its amendment states: ${ }^{24}$

1) To grant the Petitioner's petition;

1.1) The phrase "interested third parties" in Article 80 of Law Number 8 of 1981 concerning Criminal Procedure Law (State Gazette of the Republic of Indonesia of 1981 Number 76, Supplement to State Gazette of the Republic of Indonesia Number 3209) is contrary to the Constitution of the Republic of Indonesia Indonesia of 1945 as long as it is not interpreted as "including victim-witnesses or reporters, nongovernmental organizations or community organizations;"

\footnotetext{
23 Ilyas, Amir \& Nusa, Apriyanto, Op.Cit. (pp. 14)

$24 \quad$ Ibid, (pp. 15)
} 
1.2) The phrase "interested third parties" in Article 80 of Law Number 8 the Year 1981 concerning Criminal Procedure Law (State Gazette of the Republic of Indonesia Year 1981 Number 76, Supplement to State Gazette of the Republic of Indonesia Number 3209) does not have binding legal force as long as it is not interpreted. including victimwitnesses or reporters, non-governmental organizations or, community organizations. "

2) Order the loading of this decision in the State Gazette of the Republic of Indonesia as appropriate.

Based on the Constitutional Court Decision No. 98 / PUU-X / 2012, it provides a clear confirmation that what is meant by "interested third parties" as pretrial applicants as referred to in Article 80 of the Criminal Procedure Code, consists of: 25

1) victim-witness;

2) Reporters; and

3) Non-governmental organizations (NGOs) or;

4) Community Organization.

As in the Constitutional Court Decision Number 98 / PUU-X / 2012 Regarding a third party with an interest as one of the pretrial petitioners, the author concludes that the family is not a third party with an interest, because as we know that pretrial filing for the determination of the suspect was submitted by the suspect's son. , then as stipulated in Article 168 letter a, the child is a family by blood in a straight down line. So that the child is included as the family party.

Receiving Muhammad Ali Affandi's pretrial petition for the determination of the suspect against his father, in his consideration the judge explained the applicant's legal position as the suspect's son, in which the judge stated:26

1) Considering, the actions of the investigator or public prosecutor which contain the character of being a forced attempt in the pre-decision regime of the Constitutional Court Number 21 / PUU-XII / 2014, which is the object of the pretrial is as regulated in Article 79 of the Criminal Procedure Code, namely regarding whether or not arrest or detention is legal. , whereas the actions of the investigator or public prosecutor which do not have the character of being a coercive attempt are regulated in Article 80 of the Criminal Procedure Code, namely concerning termination of an investigation or prosecution;

2) Considering, after the Constitutional Court Decision Number 21 / PUU-XII / 2014, regarding whether or not the determination of the suspect has become the object of pretrial because it is seen as part of the investigation process which constitutes a deprivation of human rights and contains the nature of a forced attempt so that the regulation regarding the legal subject of the pretrial applicant regarding whether or not the determination of the suspect is valid refers to the provisions

Ibid. (pp. 16)

Putusan Praperadilan Nomor 28/Praper/2016/PN.Sby, hlm. 85 
of Article 79 of the Criminal Procedure Code, based on the systematic interpretation method;

3) Considering, the punctuation between the phrase "suspect" and the phrase "family" in the formulation of article 79 of the Criminal Procedure Code is a comma (,) punctuation which has the meaning as an alternative. This means that the "suspect" or "family" is a legal subject who has his legal entity and legal authority (independently), in the sense that if the suspect has acted as a pretrial petitioner, the family concerned will no longer be able to take the same legal steps regarding the problem. at the same time, not legally mandatory (power of attorney);

4) Considering, because the legal subject of the applicant in casu, namely MUHAMMAD ALI AFFANDI, is the biological child of H. Ir. LA NYALLA MAHMUD MATTALITTI, then MUHAMMAD ALI AFFANDI is included as a "family" who can act as legal subjects of pretrial applicants regarding whether or not the determination of the suspect against his father is legal, namely $H$. Ir. LA NYALLA MATTALITTI.

Based on the description of the judge's consideration regarding the receipt of the pretrial request in the decision Number 28 / Praper / 2016 / PN.Sby, in his consideration, the judge did not consider the existence of a suspect who was a fugitive or had the status of the wanted list (DPO). The judge only considers that the submission of pretrial by the suspect's family as stipulated in Article 79 of the Criminal Procedure Code is a legal entity and legal authority, meaning that the family does not need to obtain a power of attorney from the suspect to file a pretrial.

Based on the description that has been described, it can be concluded that the family has the legal standing to propose a pretrial on the determination of the suspect. However, the judge should still consider the existence of a suspect with the status of the wanted list (DPO). The failure to consider the status of the wanted person list (DPO) attached to the suspect implies that the principle of legal certainty is not applied, because the legal process against the suspect is delayed. The submission of pretrial against the determination of a suspect submitted by a suspect with the status of the wanted list (DPO) is legally unjustified. This was then reinforced by the existence of SEMA No.1 of 2018 concerning the Prohibition of Proposal for Suspects who have Runaway or are in the Status of the Search for Person (DPO) which was published on 23 March 2018.

As we know, SEMA has legality, so the contents of SEMA should be binding on judges and courts. The meaning is that judges and courts are obliged to comply with the regulations that have been issued so that the implementation of the duties and functions of the court can be carried out properly. SEMA is a 
regulation based on the Supreme Court Regulation (PERMA) and statutory regulations. ${ }^{27}$

SEMA is binding so that violations of the contents of SEMA by judges and courts of lower rank can be used as an excuse to cancel decisions and reject these requests by judges and higher courts. Or if the outline or instructions contained in the SEMA are not obeyed by the judge or court, the parties concerned can request legal protection from a higher court in the context of implementing the supervisory function, so that the violation is corrected and rectified according to what is outlined by SEMA. ${ }^{28}$

Apart from that based on the provisions of Article 5 jo. Article 20 of the 1945 Constitution, the backbone of the legal state of the Republic of Indonesia is Law and Government Regulations as outlined in a written or codified form. So the authors argue that although SEMA is not a statute, only an internal regulation as a technical guide for judges SEMA has a constitutional legality basis so that the content and instructions outlined therein are binding to be obeyed and applied by judges and courts.

\section{Conclusion}

Based on the description that has been elaborated, we can conclude that pretrial filings by suspects with the status of the wanted list (DPO) cannot be justified. Because as we know, the purpose of pretrial is only to supervise the existence of coercion in the investigation process, detention, and prosecution by law enforcement officials in the process of enforcing criminal acts. So that in cases of submission of pretrial applications filed by suspects who have DPO status due to the behavior of suspects who do not have good faith to fulfill summons of examination in succession and there is no element of coercion during the examination process to prosecution by law enforcement officials, firmly the request cannot be justified. Besides, pretrial filing of suspects with DPO status has resulted in legal consequences, namely the failure to apply the principle of legal certainty, following the validity of the determination of the suspect as an object extension in the Constitutional Court decision Number 21 / PUU-XII / 2014, in pretrial matters as referred to in Article 82 paragraph (1) letter b of the Criminal Procedure Code, as well as article 12 paragraph (1) of Law Number 48 of 2009 concerning Judicial Powers, in principle a suspect must be physically able to find out his whereabouts. This is reinforced by the issuance of SEMA No.1 of 2018 concerning the prohibition of pretrial filings for suspects who have fled or are currently on the wanted list (DPO) status. Although the existence of SEMA is only an internal regulation as a technical guideline for judges, however, the strength of SEMA is the same as statutory regulations.

\footnotetext{
27 Harahap, M. Yahya. (2014). Kekuasaan Mahkamah Agung Pemeriksaan Kasasi dan Peninjauan Kembali Perkara Perdata. Sinar Grafika (pp. 176). 


\section{References}

\section{Books}

Amiruddin, dan Zainal Asikin. (2012). Pengantar Metode Penelitian Hukum. Jakarta: PT. Raja Grafindo

Hamzah, Andi. (2013). Hukum Acara Pidana Indonesia. Jakarta: Sinar Grafika.

Harahap, M. Yahya. (2012). Pembahasan Permasalahan Dan Penegakan KUHAP Pemeriksaan Pengadilan, Banding, Kasasi, Dan Peninjauan Kembali. Jakarta: Sinar Grafika.

- 2014. Kekuasaan Mahkamah Agung Pemeriksaan Kasasi dan Peninjauan Kembali Perkara Perdata. Jakarta: Sinar Grafika.

Hartono. (2012). Penyidikan dan Penegakan Hukum Pidana Melalui Pendekatan Hukum Progresif. Jakarta: Sinar Grafika.

Hiariej, Eddy O.S. (2016). Prinsip-Prinsip Hukum Pidana Edisi Revisi. Yogyakarta: Cahaya Atma Pusaka.

Ilyas, Amir dan Apriyanto Nusa. (2017). Praperadilan Pasca Putusan Mahkamah Konstitusi. Yogyakarta: Genta Publishing

Marzuki, Peter Mahmud. (2011). Penelitian Hukum. Jakarta: Prenada Media Group.

. (2016). Penelitian Hukum Edisi Revisi. Jakarta: Prenada Media Group

Ramelan. (2006). Hukum Acara Pidana Teori dan Implementasinya. Sumber Ilmu Jaya.

Santoso, Lukman dan Yahyanto. (2016). Pengantar Ilmu Hukum. Malang: Setara Press.

Sofyan, Andi Muhammad. (2017). Hukum Acara Pidana Suatu Pengantar. Jakarta: Kencana

Soeparmono. (2015). Praperadilan dan Penggabungan Perkara Gugatan Ganti Kerugian dalam KUHAP. Bandung: CV Mandar Maju

Waluyo, Bambang. (2016). Penegakan Hukum di Indonesia. Jakarta: Sinar Grafika

Act

Undang-Undang Nomor 8 Tahun 1981 tentang Kitab Undang- undang Hukum Acara Pidana

Undang- undang Nomor 30 tahun 1950 tentang Mahkamah Agung Indonesia

Peraturan Kepala Badan Reserse Kriminal Kepolisian Negara Republik Indonesia Nomor 3 Tahun 2014 tentang Standar Operasional Prosedur Pelaksanaan Penyidikan Tindak Pidana

Peraturan Kepala Polisi Republik Indonesia Nomor 14 Tahun 2012 tentang Manajemen Penyidikan Tindak Pidana

Putusan Mahkamah Konstitusi Nomor 21/PUU-XII/2014

Putusan Mahkamah Konstitusi Nomor 98/PUU-X/2012

\section{Journal}

Daniel Ch. M. Tampoli. (2016). Penghentian Penuntutan Perkara Pidana Oleh Jaksa Berdasarkan Hukum Acara Pidana. In Journal. 4(2).

Arly Y. Mangoli. (2016). Eksistensi Peradilan In Absentia Dalam Hukum 
Acara Pidana Di Indonesia. In Journal. 5(3).

Tumian Lian Daya Purba. (2017). Praperadilan Sebagai Upaya Hukum Bagi Tersangka. In Papupa Law Journal. 1 (2).

\section{Website}

Ferdinan. Sidang Praperadilan La Nyalla Digelar Hari Ini. Retrieved March 30, 2016 from https://m.detik.com/news/berita/3175470/sidangpraperadilan-la- nyalla digelar-hari-ini

Elza Astari Restaduari. La Nyalla Kembali Ajukan Praperadilan Kini Atas Nama Anaknya. Retrieved May 4, 2016 from https://m.detik.com/news/berita/32 03588/la-nyalla kembali-ajukanpraperadilan-kini-atas-nama- anaknya

Toni S.H. Pengertian DPO dan dasar hukumnya. Retrieved March 20, 2017 from https://www.pengacarahandal.com/pengertian-dpo-dandasarhukum

Pengertian Akibat Hukum. Retrieved January 14, 2017 from https://www.suduthukum.com/2017/01/pengertian-akibat-hukum

Kamus Besar Bahasa Indonesia. Retrieved May 20, 2018 from http://kbbi.web/ 